\title{
Research on Integrated Crop-Livestock Systems in Brazil ${ }^{1}$
}

\author{
A pesquisa em Sistemas Integrados de Produção Agropecuária no Brasil
}

\author{
Anibal de Moraes²*, Paulo César de Faccio Carvalho³ ${ }^{3}$, Sebastião Brasil Campos Lustosa ${ }^{4}$, Claudete Reisdorfer \\ Lang $^{2}$ e Leonardo Deiss ${ }^{5}$
}

\begin{abstract}
Integrated crop-livestock systems (ICLS) are designed to exploit synergisms and emergent properties resulting from interactions between different soil-plant-animal-atmosphere compartments that integrate themselves at different spatial-temporal scales. In this review, a panorama of the evolution of studies based on ICLS is presented. Specific keywords were used as search terms to construct a database of 450 articles from 93 national and international journals published up to and including 2013. These articles were classified according to the region of origin within Brazil (subtropical or tropical) and categorized regarding the studied components: soil, plant, animal and 'others'. Within these components, groups of variables that could characterize the different thematic lines were listed. The number of publications worldwide has been increasing, and Brazil is one of the main suppliers of scientific work within this area. Although the number of scientific studies seeking better understanding of ICLS may have increased in Brazil, further studies with a systematic view and with larger temporal and spatial scales are still required to help identify interactions between diverse biotic and abiotic factors that define new properties that emerge from these systems.
\end{abstract}

Key words: Conservation agriculture. Sustainability. Scientific production. Agricultural technology. Systematic approach.

\begin{abstract}
RESUMO - Os sistemas integrados de produção agrícola e pecuária são caracterizados como sistemas planejados para explorar sinergismos e propriedades emergentes, resultado de interações entre os diferentes compartimentos solo-plantaanimal-atmosfera, que se integram em diferentes escalas espaço-temporais. Nesta revisão é apresentado um panorama da evolução das pesquisas embasadas em uma produção integrada entre os diferentes compartimentos. Considerou-se o período até 2013 e palavras-chave como fator de busca, sendo construída uma base de dados, partindo de um universo de 450 artigos em 93 periódicos nacionais e internacionais. Estes artigos foram classificados de acordo com a região de origem do Brasil: subtropical ou tropical; e categorizados quanto aos componentes: solo, planta, animal e outros. Dentro desses componentes foram elencados grupos de variáveis que caracterizassem diferentes linhas temáticas. As publicações no mundo têm aumentado e o Brasil está entre os principais provedores de trabalhos científicos nessa área. Embora seja crescente o número de trabalhos científicos no Brasil, que buscam melhor compreensão dos sistemas integrados de produção agrícola e pecuária, as pesquisas com visão sistêmica e de maior escala temporal e espacial ainda necessitam de mais estudos, para que possam detectar interações entre os diversos fatores bióticos e abióticos e novas propriedades que emergem destes sistemas.
\end{abstract}

Palavras-chave: Agricultura conservacionista. Sustentabilidade. Produção científica. Tecnologia agropecuária. Enfoque sistêmico.

\footnotetext{
*Autor para correspondência

${ }^{1}$ Recebido para publicação em 21/04/2014; aprovado em 26/06/2014

Este trabalho foi auxiliado por bolsa de produtividade em pesquisa do CNPq

${ }^{2}$ Departamento de Fitotecnia e Fitossanitarismo, Universidade Federal do Paraná, Rua, Dos Funcionários, 1.540, Curitiba-PR, Brasil, 80.035-050, anibalm@ufpr.br, langc@ufpr.br

${ }^{3}$ Faculdade de Agronomia, Universidade Federal do Rio Grande do Sul, Av. Bento Gonçalves 7712, Caixa Postal 776, Porto Alegre-RS, Brasil, 91.501-970, paulocfc@ufrgs.br

${ }^{4}$ Universidade Estadual do Centro-Oeste, Rua, Camargo Varela de Sá 03, Guarapuava-PR, Brasil, 85.040-080, slustosa@unicentro.br

${ }^{5}$ Programa de Pós Graduação em Agronomia/Produção Vegetal, Universidade Federal do Paraná/UFPR, Rua, Dos Funcionários, 1540, Curitiba-

PR, Brasil, 80.035-050, leonardodeiss@ufpr.br
} 


\section{INTRODUCTION}

Many regions of the world already face a scenario of complete food insecurity, which is projected to increase in the future. The current challenges of agriculture include circumventing the problems arising from decades of using farming practices with high environmental impact, mitigating emissions of greenhouse gases, reducing the erosion and loss of fertility of soils, reducing the silting of watercourses and preventing soil and water pollution, among others. Integrated crop-livestock systems (ICLS) are considered to be key among sustainable technologies to achieve these goals.

The benefits of ICLS include: i) improvement of the production processes, including improvements in the workforce, stability of economic factors and risk reduction, ii) greater chances of producers reaching their socio-cultural aspirations in an equitable way and iii) greater food security to meet the needs of consumers regarding the quality of the products and production processes (FAO, 2010). Furthermore, a high level of biodiversity is maintained, which is essential to support the intensive agricultural systems required to achieve food security and reduce environmental degradation while concomitantly adapting agriculture to climate change.

\section{What is meant by an integrated crop-livestock} system?

Integrated crop-livestock systems are characterized as systems designed to exploit synergisms and emergent properties that result from interactions in the soil-plantanimal-atmosphere compartments in areas that integrate crop and livestock production activities on different spatial-temporal scales, covering the exploitation of agricultural crops (farming and forestry) and animal production (e.g., meat, milk and wool, among others) in the same area concurrently or sequentially in rotation or succession (MORAES et al., 2013).

In Brazil, these systems are recognized by the acronym ILP, corresponding to associations between livestock for meat or milk with crops of soybeans, maize, beans, rice, eucalyptus and cotton, among others, usually on the scale of farms (CARVALHO; MORAES, 2011). Globally, the concept is much broader, involving the integration between rural properties and even between scales of landscapes and small watersheds (KEULEN; SHIERE, 2004).

\section{Integrated crop- livestock systems in perspective: past, present and future research}

Although they are not new, ICLS are undergoing rapid evolution, and the innovation that Brazilian science brings to the world is the use of these systems under the pillars of conservation agriculture. No-till farming and its soil-cover requirements, combined with a diversity of rotations and the effects of grazing, interact synergistically and contribute to new properties of ICLS. The result within the system is greater than the sum of the contributions from individual technologies, leading to the application of the concept of emergent properties (ANGHINONI; CARVALHO, COSTA, 2013). In this sense, the prevailing perception is that ICLS serves as a system in which the productivity versus conservation dichotomy has a compatible solution with the current societal demands. In addition, innovative strategies as "rotatinuous" grazing management (CARVALHO, 2013), or the whole-system fertilization approach (ANGHINONI; CARVALHO; COSTA, 2013) foster the efficiencies and sustainability of such systems.

Unfortunately, ICLS are still not understood by many scientists and rural producers, being marginalized as production systems for small stakeholders where the integration is performed without the necessary supply of inputs and with minimal use of "intellectual technology". Likewise, producers who claim to work with ICLS and do not use the basic concepts, such as no-till, sound pasture management and whole-system fertilization approach, normally obtain unsatisfactory results and eventually claim inefficiency of the ICLS used.

To provide an overview of how research is being developed in Brazil regarding ICLS, it is necessary to evaluate where the approach is functioning, what methods have been studied and what can be done to harness the potential of these production systems based on the study of Brazilian publications. Aiming to assess the Brazilian scientific production, a review will be presented to determine the current state of knowledge in ICLS, and to contrast it with the rest of the world.

\section{Scientific production on integrated crop-livestock systems and brazilian representation on a global scale}

Studies of integrated crop-livestock systems have been conducted in different environments and with different configurations of grain crops, forestry components, types of animals and associated forage substrates (BENAVIDES; DOUGLAS; OSORO, 2009; NAIR, 1993). With regard to Brazil, scientific research on ICLS came to prominence in the 1980s. Since the inception of this research, the apparent scarcity of experiments with a systematic focus became apparent, particularly studies that considered the effects of interactions between the various biotic and abiotic factors involved (SAIBRO; BARRO, 2009). 
A survey of studies was performed on Web of Knowledge using the terms "crop-livestock or agropastoral" (but see CARVALHO et al., this issue, for terminology issues), considering papers published in the period prior to and including 2013. Of the 881 articles found, 815 publications $(92.51 \%$ ) were interpreted as related to the topic of ICLS. The selection was performed primarily based on the title, followed by the abstract only when the title was not clear, and by the full text when an analysis of both the title and abstract was insufficient to select or reject the article as a study of ICLS. Publications were considered when studies evaluated technologies involving ICLS in a broad sense, seeking the intensification of land, water, light and nutrient use, and exploiting synergies between crop and livestock components.

There is a consensus among authors that this survey did not cover all the publications worldwide, or all that in Brazil, due to search engines and key words that difficult searching efficiency. However, this assessment represents a large portion of the publications and reflects the trend of how the research related to this topic has behaved.

Studies from the years 1964, 1970, 1982 and 1984 were not included in the analysis of publications evolution to improve the graphic visualization of results, but represent only one publication for each year. According to this survey, there was an increase in the interest concerning ICLS in recent years, which was reflected in the increasing number of publications worldwide in this topic. The mean annual publication rate between 1986 and 1990 was 3.2 publications year ${ }^{-1}$, well below 83.6 publications year ${ }^{-1}$ registered from 2009 to 2013 (Figure 1a).
Among selected articles, only $1.1 \%$ was related to the topic of ecosystem services, and these articles would be selected by adding the search term "ecosystem service" to the others terms used. Ecosystem service analysis is a contemporary topic and demands many studies, preferentially analysis that cover the four main groups of ecosystem services (see MEA, 2005 for more details).

Brazil is among the main worldwide suppliers of scientific work in ICLS topic, being ranked in first place with 180 publications, followed by the U.S.A., France and Ethiopia with 177, 94 and 76 publications, respectively (Figure 1b).

\section{Assessment of brazilian research on integrated crop-livestock systems}

To evaluate the Brazilian scientific production on ICLS, a database was built covering the years from 1994 to 2013 and based on 93 national and international journals. The first step was searching in the Web of Knowledge using the same terms described previously (crop-livestock or agropastoral) and adding the term "*Brazil". Based on this procedure, 31 journals were identified, of which 26 met the selection criteria described previously. To extend the search of published studies, Google Scholar was used to search the aforementioned terms as well as the terms "integração lavoura-pecuária [crop-livestock integration]" and "sistema integrado [integrated system]" to better capture the series of Brazilian publications that could have not included by search engines that operate only with indexed journals. Only publications in journals were selected, which eliminated from the search theses, dissertations, technical bulletins and booklets. All

Figure 1 - Annual publications from 1986 to 2013 (a) and relative participation (\%) of the main countries in publications (b) concerning ICLS

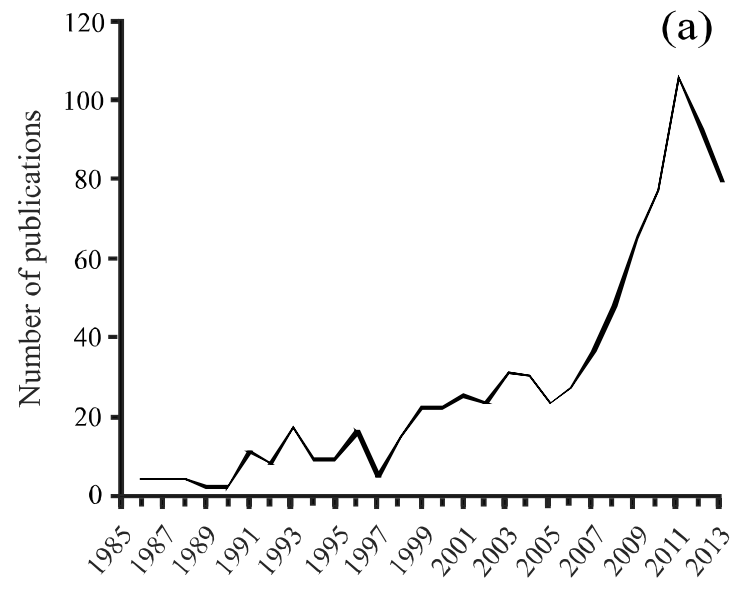

Years

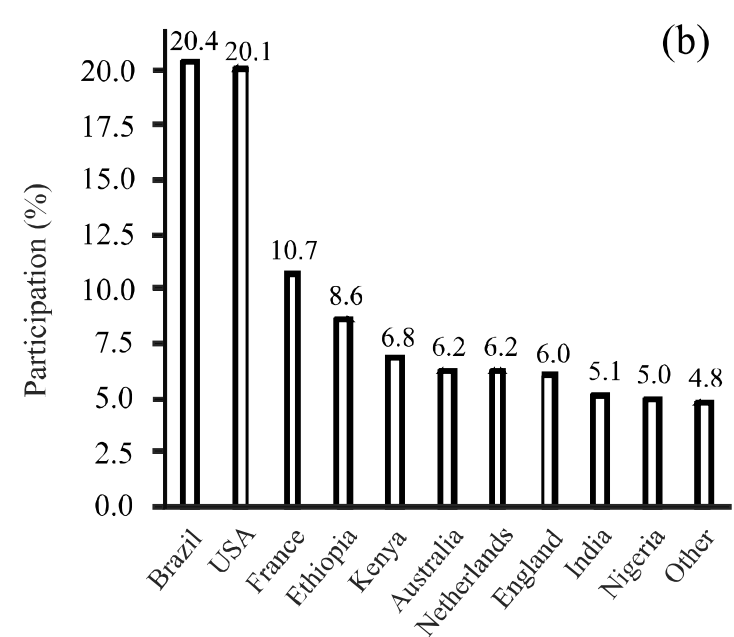

Countries 
the evaluated publications during the period went through the same selection process described above in addition to have been conducted within Brazilian territory.

The publications were classified into two categories according to their region of origin: 1) a subtropical region south of Brazil and 2) a tropical region Southeast, Midwest, Northeast and North of Brazil. Four categories were also defined for the system components: soil, plants, animals and others. Within these components, groups with variables that characterized different topics were categorized, as shown in Figure 3.

The number of studies in search results indicates that ICLS research have been experiencing a significant increase (Figure 2a). In the last 19 years, of the 93 listed journals, eight represented $60.22 \%$ of the publications. Of the total publications, only $19.77 \%$ were published in international journals, and of this fraction, only 5 articles were published annually up to 2009 . After 2010 , this number rose to more than 9 annually. The year 2013 was noteworthy because 20 articles were published in international journals, with the largest share of studies related to the mitigation of greenhouse gases and carbon sequestration (e.g., PIVA et al., 2013) and to promoting the diversification of agricultural activities (e.g., BONAUDO et al., 2013; LEMAIRE et al., 2013; SALTON et al., 2013), indicating the importance that these topics have acquired in recent years. However, the quantitative progress appears not to have been accompanied by publications quality: few publications regard to the development of conceptual models grounded in understanding of the underlying processes involved. Instead, they focus on outputs resulting from these processes, so cause-effect relationships cannot be established.

Regarding the regional distribution, $37.8 \%$ of the studies were performed in subtropical region, whereas $62.2 \%$ of the studied were performed in tropical region. From a scientific point of view, few research groups have generated data regarding soil/ plant/animal/climate components in long-term studies. Data on ICLS including grains, pasture and trees are the result of studies coming almost exclusively from universities and public research institutes.

The studies of ICLS initially addressed economic alternatives to the cultivation of winter cereals and crop rotation under no tillage in the southern region, without any concern for studying the animal component. Few studies considered the presence of trees within the system. Later, with the feasibility of using winter pastures in the rotations used in the subtropical region, the effects on physical soil characteristics became a topic of study, an aspect that occupied the thoughts of most experts and producers. Regarding the mid western region, due to the economic advantages of degraded pasture recovery with agriculture and the advantages of pasture to maintain soil cover in no-till farming, the number of studies of the intercropping of pastures and normal-cycle and off-season crops increased. To this end, studies focused on the forms of establishment and the use of herbicides in the intercropping systems.

Regarding the components of ICLS, the vast majority of the research studies found were related to plant

Figure 2 - Number of studies (a), relative distribution of the plant, soil, animal and other components (b) and of variables selected within the plant component c), the soil component (d), the animal component (e) and the 'others' component (f) in 450 scientific articles published between 1994-2013 on integrated crop-livestock systems

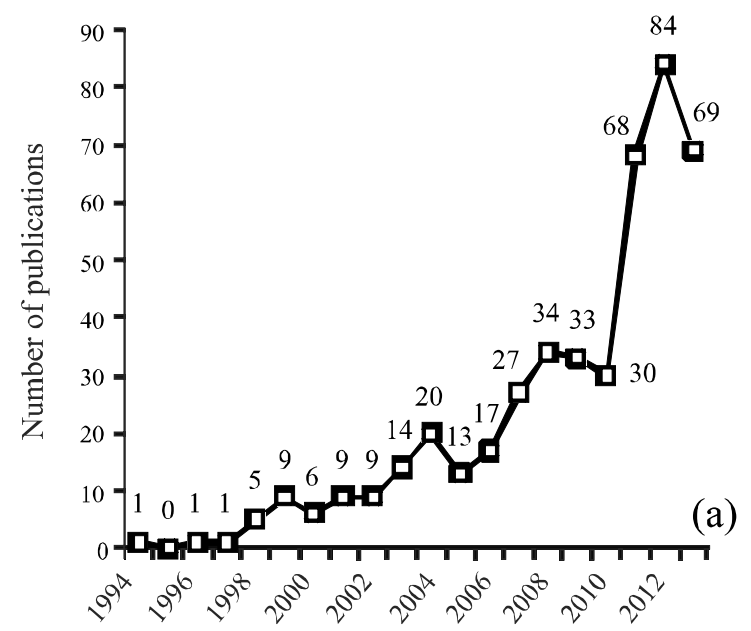

Years

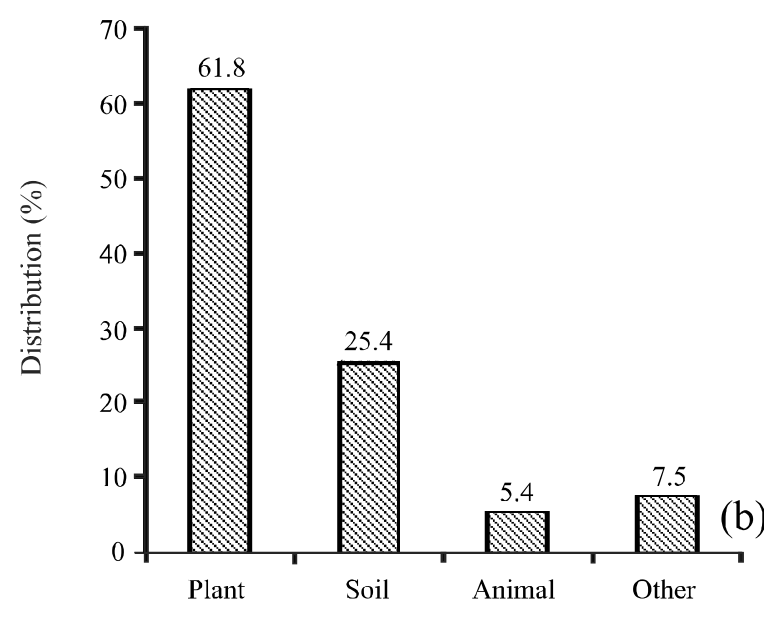

Components 
Figure 3 - Relative distribution of the variables selected within the plant component (a), the soil component (b), the animal component (c) and the 'others' component (d) in 450 scientific articles published between 1994 and 2013 on integrated crop-livestock systems
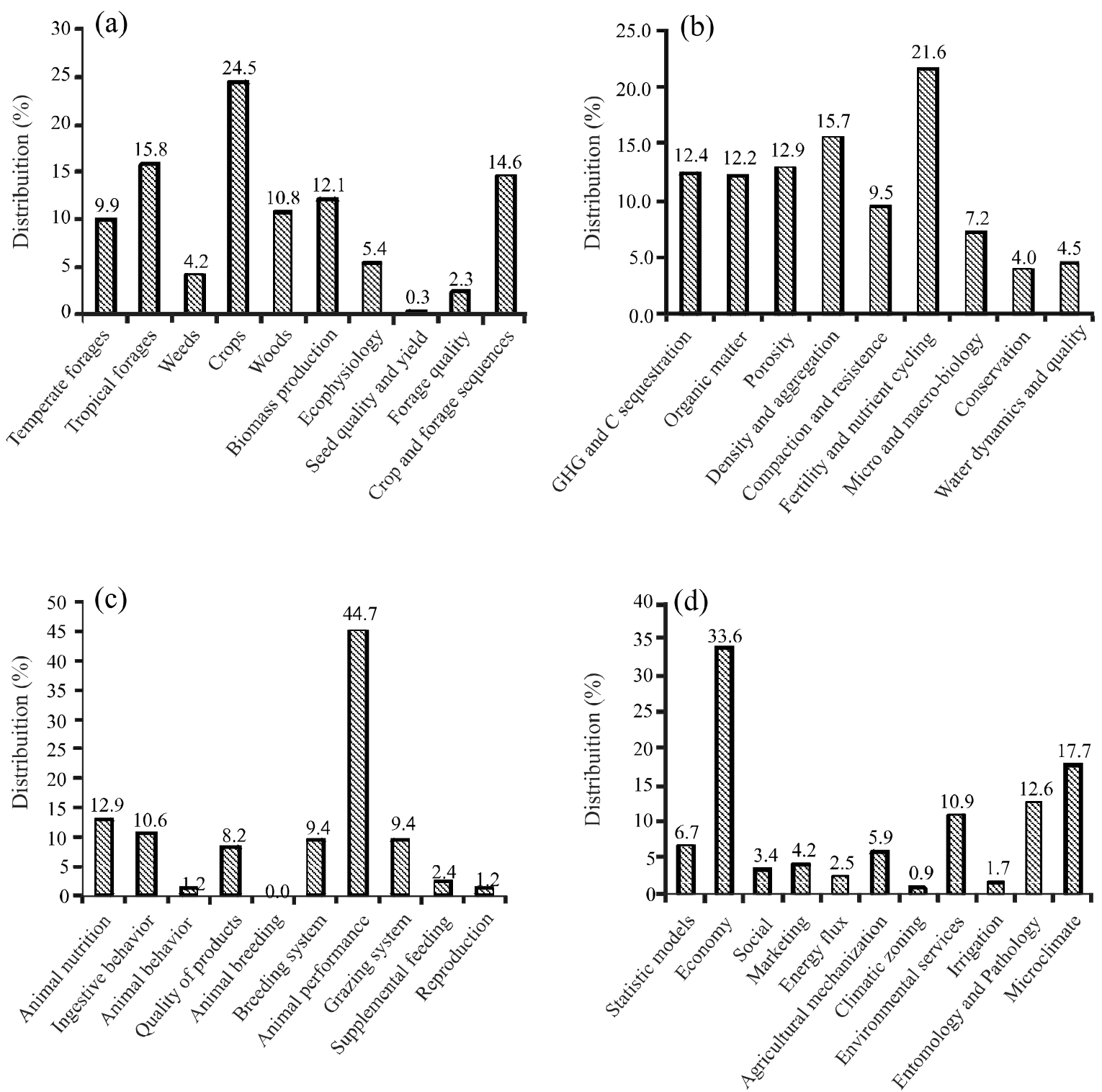

production, focusing primarily on the yield of annual crops. Few of the studies involved the soil, animal and other components (Figure 2b); only $4.67 \%$ of the articles jointly discussed the soil/plant/animal components. The perception is that there is still dissociation between these components, given that the researchers ultimately disregarded the interrelations of the components for various reasons. Moreover, experts and producers consider livestock and silviculture as secondary components to annual crops.

When the plant component is analyzed (Figure 3a), temperate and tropical forage crops were mostly examined merely as soil-cover crops; research that concerns their

production often without considering the effects of animals, fertilizer treatments, period of establishment, intercropping with crop plants or herbicide tolerance.

Another finding is that the plant species were limited to a few alternatives, such as oats/ryegrass in the subtropics and Brachiaria (Urochloa)/Panicum (Megathyrsus) in the tropics, although there are several forage options these regions. This trend might indicate constrains to the establishment of more diversified systems.

Only recently the investigation in ICLS encompasses studies with forage species tolerant to shaded environments, the adaptation of tree species in 
pastoral environments, breeding of dual-use materials as both grain and forage, the environmental effects of trees on the quality of the forage produced, the amount of residual biomass under different Brazilian conditions and the quality of biomass produced by different combinations of grains and forage species. Studies that have tested different tree arrangements and their long-term ecological and economic implications regarding the animal and herbaceous plant components, as well as the balance of the system as a whole, are incipient. In other words, there are many research topics to be explored in ICLS due to the complex nature of the involved components.

The few studies on weeds have focused on the application of herbicides to reduce pasture competition, enabling crop development and weeds control. Grazing is not a subject in the sense of weed control. However, sound grazing intensity can be an important biological method of weed control (PELISSARI et al., 2013). This control strategy, in association with herbicide management, may significantly hinder the problem of herbicide-resistant plants in ICLS. There are also few publications on the rational use of agrochemicals. Indeed, most of the studies involving ICLS do not consider the aspects of phytosanitary products, so that such products may be legally registered and correctly utilized in farming. Another need regards studies on the planning crop rotations that balance grains and forage production, with or without trees, within the goal of animal production (meat, milk, wool, etc.) using perennial tropical pastures.

Regarding the tree component, there is another lack of diversity exposed by the analysis of investigated species. The majority of the researches have been produced with exotic species. There is a growing concern for working with native species, but there is resistance in doing so because native species have slower growth rates, in addition to the legal obstacles to its cultivation and use. Another factor to consider is the establishment of tree species and the interactions of these species with well-established agricultural practices and the presence of grazing animals.

In the soil component (Figure 3b), variables related to physical attributes porosity, density and aggregation, compression and penetration resistance are the most commonly studied, corresponding to $38.06 \%$. However, many of the publications that focus on these variables require minimal information regarding stocking rate, grazing method (continuous or rotational) and pasturemanagement practices during the experimental period. The studies are only occasionally directed to determine the possible effect of animals. Other factors are not explored, such as the movement of machines and implements, as well as the regenerating effects of roots.
With respect to the soil properties, the quantification of carbon stocks and the effects of soil organic matter are often encompassed, as well as the biological and chemical attributes. Few studies correlate the time usage dimension of an area with the aerial biomass production and especially with root biomass. Studies on greenhouse gases are also emerging but remain incipient in Brazil, particularly due to difficulties in methodologies and facilities that enable intermittent measurements over the time span of a day to several days in long-term experiments.

Soil fertility has been widely studied in the context of nutrient cycling, but there is still a lack of knowledge regarding the turnover of cycled nutrients via manure and urine, the effects of the mineral supplements on some microelements, the number, volume and content of the excreta of different animal species used and the effect of diet on the resulting fertility. Regarding fertilization, studies on systemic application and the conceptualization of fertilization strategy remain scarce. In general, there is limited knowledge on how the cycling of nutrients occurs in environments that integrate herbaceous plants, trees and animals, hindering safe recommendations for the whole-system fertilization approach.

As mentioned before, one of the ICLS pillars is no-till, but few studies have analyzed soil and water conservation, with only $8.46 \%$ of the articles addressing soil and water loss, water supply, horizontal and vertical water dynamics or the transport of nutrients and pollutants that affect water quality. Conservation practices in ICLS are also incipient, as if the adoption of no-till by itself could guarantee soil conservation.

Compared to the plant component, the animal component has received much less attention (Figure $3 \mathrm{c}$ ). This result reinforces the finding that the majority of published studies give greater attention to crop-plant production. The few experiments with grazing record levels of animal performance in ICLS that are roughly twenty times greater than that of pure pasture systems. However, the animal component remains poorly studied given the complexity of pasture cycle and grazing ecology. The majority of studies concentrate on cattle and sheep, with emphasis on the former. Information relating to buffaloes and goats is scarce. Studies related to animal behavior, genetics and reproduction are almost nonexistent in ICLS, and these topics could be relevant due to animal welfare requirements and challenges to the genetic potential of animals by offering a usual high-quality diet allowed by ICLS. Additionally, the quality of animal products produced in ICLS has received little attention from researchers, although this quality is a relevant aspect in the commercialization of these products and in the purchasing decisions of consumers.

Regarding other factors related (Figure 3d), economic and microclimate aspects stand out. There 
is a need for advances relating to the organization of knowledge in social sciences to be able to provide a systematic view, especially regarding interactions outside of the farm. This topic has been addressed to a greater extent in the international literature compared to that of Brazil. Although there is much discussion on the beneficial effects of ICLS with planned rotations and high diversity on the control of diseases and pests, few studies have been published on this subject. This issue could lead to a better use of phytosanitary products or highlight the effects of biological control allowed by ICLS. The number of publications related to the topic of ICLS agricultural mechanization is also incipient, as well as studies on the energy balance compared to traditional monocrop models. Moreover, economic aspects are poorly addressed, and present data remain insufficient given the currently demanding investments in ICLS.

\section{Future actions in integrated crop-livestock systems}

In the design of new research studies related to ICLS, a major challenge is to maintain long-term experimental protocols so that the extent of the effects may be detected. Various parameters (e.g., C stocks in the soil) require monitoring periods that most of the research-grants programs do not consider. ICLS research also demands multidisciplinary teams that transcend a mere union of experts from diverse areas. More than multidisciplinary and pluri-disciplinary, and even more than interdisciplinary, a transdisciplinary level of research organization is required because the study of emergent properties requires studies on the level of underlying processes.

Few researchers seem proficient for that approach, which reflects the limitation of experimental designs that encompass the required level of comprehension. Only the transdisciplinary level would enable researchers to adequately answer the fundamental question: "What are the new processes involved in the different energy, water and nutrient flux pathways and the alterations in the efficiency in the use of these components?" A fundamental understanding is needed to guide a more-adequate utilization of nutrients, complying with a huge societal demand for a renewed agriculture that is to "produce more food per unit area with less necessity for nutrient and water replacement."

Another challenge relates to the payments for ecosystem services, which may play a role in the reduction of costs arising from sustainable intensification of agriculture promoted by ICLS. However, payments for these services are subject to various constrains that may make it difficult to apply and for a more widespread adoption (MONTAGNINI; FINNEY, 2011).

A gap to be filled in the near future concerns the lack of design and development of machines that meet the specifications of ICLS. Another point concerns plant germplasm to enlarge diversification options in terms of plant development periods that would be not oriented towards the maximum individual crop yield. Conversely, ICLS require germplasm that combined yield with other crops in sequence, as well as with other components (trees and animals). In other words, genetic material for combined production of the entire system. There is evidence that more forage biomass is produced cumulatively when pasture phase is grazed compared to non-grazed pasture cover (KUNRATH, 2011). Therefore, the sum of the results of the spatial and temporal combinations is more important than the yields of the mono-specialized systems.

Statistics relating to areas used with ICLS in Brazil are poor and do not describe its correct dimensions. From the scarce information, it is estimated that nearly $5 \%$ of the annually cultivated areas already apply this system to some degree (MACEDO, 2009). Therefore, the generation of parameters for the planning of public policies, dissemination of information and training of human resources with an economic and social developmental view is severely restricted.

Furthermore, conflict has been observed among agricultural science professionals regarding continuing training and updating when faced with complex crop systems, such as ICLS, compared with conventional agricultural production systems.

\section{CONCLUSIONS}

1. Although the number of scientific studies in Brazil that seek to better understand ICLS is increasing, few of these studies are actually conducted with a systemic and holistic approach. Instead, studies often ignore larger temporal and spatial scales that may be necessary to detect interactions between the diverse analyzed variables and the properties that emerge from such systems;

2. Integrated crop-livestock systems can guarantee the sustainable intensification of agriculture, promoting increased production of foods, fibers and energy, associated with the promotion of ecosystem services. Furthermore, the adoption of ICLS depends on the availability of information regarding the agronomical and economical potential, the market demands and the existence of governmental policies for sustainable development;

3. In the context of public policy, the limitations remaining in rural extension and technical assistance constitute important barriers to the adoption of ICLS. Therefore, aside from the scientific question, there is an urgent need for training and qualification of professionals with a systemic view, ensuring that the projects in this field are economically viable, environmentally sustainable, 
socially fair, culturally accepted and ethically correct. As such, the scope of the main goal of ICLS, given the five aforementioned needs, depends on the generation of knowledge that should be used to create basic concepts that are fundamental for the development of new sustainable technologies to be applied by rural producers.

\section{ACKNOWLEDGEMENTS}

Este trabalho foi auxiliado por bolsa de produtividade em pesquisa do $\mathrm{CNPq}$, e pelo Projeto de Redes Nacionais de Pesquisa em Agrobiodiversidade e Sustentabilidade Agropecuária - REPENSA, Processo 562688/2010-2.

\section{REFERENCES}

ANGHINONI, I.; CARVALHO, P. C. F.; COSTA, S. E. V. G. A. Abordagem sistêmica do solo em sistemas integrados de produção agrícola e pecuária no subtrópico brasileiro. In: Eds. Araújo, A. P.; Avelar, B. J. R. Tópicos Ci. Solo, 8. ed., Viçosa - MG UFV, 2013. pp. 221-278.

BENAVIDES, R. DOUGLAS, G. B.; OSORO, K. Silvopastoralism in New Zealand: review of effects of evergreen and deciduous trees on pasture dynamics. Agroforestry System, v. 76, p. 327-350, 2009.

BONAUDO, T. et al. Agroecological principles for the redesign of integrated crop-livestock systems. European Journal of Agronomy (2013), http://dx.doi.org/10.1016/ j.eja.2013.09.010

CARVALHO, P. C. F.; MORAES, A. Integration of Grasslands within Crop Systems in South America. In: Eds. LEMAIRE, G.; HODGSON, J. CHABBI, A. Grasslands Productivity and Ecosystems Services. Oxford shire - UK: CABI, 2011. p. 219-226.

CARVALHO, P. C. F. Can grazing behavior support innovations in grassland management? In: Proceedings of the 22nd International Grassland Congress, 2013. p. 1134-1148.

FAO, FOOD AND AGRICULTURE ORGANIZATION OF THE UNITED NATIONS. Sete Lagoas consensus. In: FAO. An international consultation on integrated crop-livestock systems for development, Rome: FAO, 2010. p. 1-3.

KEULEN, H.; SCHIERE, H. Crop-livestock systems: old wine in new bottles? In: Fischer, T. et al. (Eds.). New directions for a diverse planet. Proceedings of the IV International Crop Science Congress, Australia, 2004. 1 CD ROM.
KUNRATH, T.R. Impactos da altura de manejo do pasto em sistemas de integração lavoura-pecuária. 2011. Dissertation - Universidade Federal do Rio Grande do Sul [Federal University of Rio Grande do Sul], Porto Alegre, Rio Grande do Sul, 2011.

LEMAIRE, G. et al. Integrated crop-livestock systems: Strategies to achieve synergy between agricultural production and environmental quality. Agriculture, Ecosystems \& Environment. 2013 (IN PRESS).

MACEDO, M. C. M. Integração lavoura e pecuária: o estado da arte e inovações tecnológicas [Crop and livestock integration: the state of the art and the near future]. Revista Brasileira de Zootecnia, v. 38, p. 133-146, 2009.

MEA - MILLENNIUM ECOSYSTEM ASSESSMENT. Ecosystems and human well-being: biodiversity synthesis. World Resources Institute: Washington, DC, 2005. 100 p.

MONTAGNINI, F.; FINNEY, C. "Payments for environmental services in Latin America as a tool for restoration and rural development", Ambio, v. 40, p. 285-297, 2011.

MORAES, A. et al. Integrated crop-livestock systems in the Brazilian subtropics. Eur. J. Agron. 2013 (IN PRESS), http://dx.doi.org/10.1016/j.eja.2013.10.004.

NAIR, P.K.R. Introduction to agroforestry. Dordrecht: Kluwer Academic Publishers, 1993. 499 p.

PAGIOLA, A. S. et al. Paying for the environmental services of silvopastoral practices in Nicaragua. Ecological Economics, v. 6, p. 374-385, 2007.

PELISSARI, A. et al. Fundamentação teórica para o controle de plantas daninhas em integração lavoura-pecuária. In: SILVA, J. F.; MARTINS, D. (Org.) Manual de Aulas Práticas de Plantas Daninhas [Manual of Practical Classes of Weeds]. 1. ed. Jaboticabal - SP: FUNEP, 2013. p. 31-43.

PIVA, J. T. et al. Soil gaseous $\mathrm{N}_{2} \mathrm{O}$ and $\mathrm{CH}_{4}$ emissions and carbon pool due to integrated crop-livestock in a subtropical Ferralsol. Agriculture, Ecosystems \& Environment. 2013 (IN PRESS).

SAIBRO J. C.; BARRO, R. S. Indicadores biofísicos e sustentabilidade em sistemas silvipastoris [Biophysical indicators and sustainability in silvopastoral systems].In: WORKSHOP INTEGRAÇÃO LAVOURA-PECUÁRIAFLORESTA NO BIOMA PAMPA [WORKSHOP ON CROPLIVESTOCK-FOREST INTEGRATION IN THE PAMPAS BIOME], 2009, Pelotas, RS. Presentation... Pelotas, RS: Embrapa ClimaTemperado, 2009. 1 CD-ROM.

SALTON, J. C. et al. Integrated crop-livestock system in tropical Brazil: Toward a sustainable production system. Agriculture, Ecosystems \& Environment. 2013 (IN PRESS). 